\title{
Physicochemical characteristics and functional properties of vitabosa (mucuna deeringiana) and soybean (glycine max)
}

Características físico-químicas e propriedades funcionais de vitabosa(Mucuna deeringiana) e soja (Glycine max) Sandra Patricia Chaparro ACUÑA ${ }^{1 \star}$, Jesús Humberto Gil GONZÁLEZ², Iván Darío Aristizábal TORRES²

\begin{abstract}
Physicochemical characteristics and functional properties of vitabosa flour (Mucuna deeringiana) and soybean flour (Glycine max) were determined. Oil absorption capacity was higher in vitabosa. Water absorption capacity was higher in soy and it was affected by the change in the ionic strength of the medium. Emulsifying Activity (EA) decreased with increasing concentration of flour, while Emulsifying Stability (ES) showed an increased. EA and ES of flours have more ionic strength in the range between 0.0 and $0.4 \mathrm{M}$, but it is reduced afterwards with the higher concentration of $\mathrm{NaCl}$. Foaming stability varied with the concentration of flour solution reaching maximum values of 39 and $33 \%$ for vitabosa and soybean, respectively at $10 \%$ flour concentration. Vitabosa had the best foaming capacity ( $56 \%$ to $0.6 \mathrm{M})$ compared with soybeans $(47 \%$ to $0.4 \mathrm{M})$. Maximum capacity of gelation was observed in vitabosa at $10 \%$ flour concentration. Increases in ionic strength of the flour solution, at low salt concentrations $(<0.4 \mathrm{M})$, improved the gelation of flours.
\end{abstract}

Keywords: oil absorption; foaming capacity; flours; vitabosa; soybean.

\section{Resumo}

Varias características físico-químicas e funcionais para farinha de vitabosa (Mucuna deeringiana) e soja (Glycine max) foram avaliadas. A vitabosa apresentou maior capacidade de absorção de óleo enquanto a soja mostrou maior capacidade de absorção de água, sendo esta última altamente dependente das mudanças na força iônica do meio. A Atividade Emulsificante (AE) diminuiu com o aumento da concentração de farinha, enquanto que a estabilidade de emulsão (ES) aumentou. Tanto para a farinha de vitabosa quanto a de soja, os valores de AE e ES incrementaram no intervalo 0,0-0,4 M. Com relação à estabilidade da espuma, esta propriedade variou com a concentração da farinha, atingindo valores máximos de $39 \%$ (vitabosa) e 33\% (soja) para uma concentração de $10 \%$. A farinha de vitabosa teve a melhor capacidade espumante $(56 \%$ para $0,6 \mathrm{M})$ em comparação com a de soja ( $47 \%$ a $0,4 \mathrm{M})$. A maior capacidade de gelificação foi observada em farinha de vitabosa para uma concentração de $10 \%$. Os resultados também mostraram que um aumento na força iônica da solução para baixas concentrações no sal $(<0,4 \mathrm{M})$, melhora a capacidade de gelificação das farinhas.

Palavras-chave: absorção de óleo; capacidade espumante; farinhas; vitabosa; soja.

\section{Introduction}

In under-developed countries, there is an urgent need to find new protein sources because meat and milk prices are often inaccessible for the majority of the population causing a rise in malnutrition rates (YUSUF et al., 2008). For this reason, research on different leguminous species has established that some seeds can be an abundant and economical protein source (MACHUKA, 2002; SIDDHURAJU et al., 2001). Soybean is one of the most important leguminous species because of its functionality, high nutritional value, and health benefits (ROSTAGNO et al., 2005; REN et al., 2006).

Mucuna deeringiana, also known as vitabosa, Mucuna Stizolobium deeringianum or dwarf plant, is native to India and belongs to Fabaceae family. It is known for its great capacity to produce cut foliage or green manure, eliminate weeds, control erosion, and improve soil (ECHEVERRI; RODRÍGUEZ, 1999). Vitabosa is a leguminous species of high nutritional value and great potential thanks to its high content of protein and other interesting compounds (VALDIVEL, 2000). The use of vegetable proteins for the development of new conventional food products has been the focus of much research in recent years. To analyze these new potential sources of protein as food ingredients, their physicochemical and functional properties should be evaluated since they play an important role in the physical behavior of food or ingredients during processing and storage. These properties include the emulsifying capacity, foaming, gelation and water and oil absorption. Some food industries are focused on finding new raw materials to improve the appearance and quality of their products, and for that reason the functional properties are important to reduce costs. This research was focused on the evaluation of the functional properties of vitabosa (Mucuna deeringiana) compared with one of the most widely used leguminous species in the world, the soybean (Glycine max).

\section{Received 15/5/2010}

Accepted 3/11/2010 (004839)

'Departamento de Boyacá, Universidad Pedagógica y Tecnológica de Colombia - UPTC, Av. Central del Norte, CEP 057 87422174,Tunja, Colombia,

e-mail: patricia.chaparro@uptc.edu.co; spchaparroa@unal.edu.co

${ }^{2}$ Departamento de Ingeniería Agrícola y de Alimentos, Departamento de Antioquia, Facultad de Ciencias Agropecuarias, Universidad Nacional de Colombia, 1779, Medellín, Colombia ${ }^{*}$ Corresponding author 


\section{Materials and methods}

\subsection{Materials}

Vitabosa seeds were obtained from the experimental farm Centro Agropecuario Cotové in Santa Fé de Antioquia at the Universidad Nacional de Colombia (Latitude: $6^{\circ} 33^{\prime} 32^{\prime \prime} \mathrm{N}$ and longitude: $1^{\circ} 44^{\prime} 43^{\prime}$ ' W, altitude: $550 \mathrm{~m}$, average temperature: $27.3{ }^{\circ} \mathrm{C}$, relative humidity $55.4 \%$, annual rain fall: $1919.3 \mathrm{~mm}$, alluvial soil from limestone and calcareous clays, tropical dry forest) (ARANGO, 2004). Soybeans were obtained from a local market in Medellin (Colombia). All chemicals used were of analytical grade.

\subsection{Physicochemical analysis}

One hundred seeds of each leguminous were weighed individually. The average weight of a seed (W) was reported in grams. Density $\left(\mathrm{g} \cdot \mathrm{mL}^{-1}\right)$ was determined by the ratio of weight of seeds to the volume of displaced water. To determine hydration capacity, the Seed Number (SN) in $100 \mathrm{~g}$ of each seed (WS) was determined, and the seeds were transferred to a test tube containing $100 \mathrm{~mL}$ of distilled water. The grains were soaked at room temperature $\left(25 \pm 2{ }^{\circ} \mathrm{C}\right)$. After 15 hours, the seeds were drained; superfluous water was removed with filter paper and the swollen seeds were separated and reweighed (HSW). Hydration capacity was calculated as $\mathrm{HC}=(\mathrm{HSW}-\mathrm{WS}) /$ $\mathrm{SN}$. Hydration index was calculated as $\mathrm{HI}=\mathrm{HC} / \mathrm{W}$. In addition, the volume of $100 \mathrm{~g}$ seeds was measured on a test tube in $\mathrm{mL}$ (SV). After 15 hours in distilled water, the volume of soaked seeds (HSV) was measured. Swelling capacity per seed was determined as follows: $\mathrm{SC}=(\mathrm{HSV}-\mathrm{SV}) / \mathrm{SN}$ and Swelling index as $\mathrm{SI}=\mathrm{SC} / \mathrm{V}$, where $\mathrm{V}$ is the volume of a seed $(\mathrm{mL})$. The moisture content was measured using the standard method $945.09 \mathrm{~B}$ (ASSOCIATION..., 2000).

\subsection{Preparation of flours}

Cleaned seeds $(2 \mathrm{~kg}$ ) of leguminous species were soaked in distilled water at $25 \pm 2{ }^{\circ} \mathrm{C}$ for 10 hours after which they were manually dehulled. The cotyledons were dried for 48 hours at $50{ }^{\circ} \mathrm{C}$. Finally, dried seeds were then milled in a hammer mill, sieved through a $0.50 \mathrm{~mm}$ mesh sieve, and kept in airtight containers at $4{ }^{\circ} \mathrm{C}$ prior to use.

\subsection{Functional properties}

\section{Water and oil absorption capacity}

Beuchat's method (1977) was employed for the determination of water and oil absorption capacity. One gram of sample was mixed with $10 \mathrm{~mL}$ distilled water for 30 seconds. The samples were then allowed to stand at room temperature $\left(25 \pm 2{ }^{\circ} \mathrm{C}\right)$ for 30 minutes after which they were centrifuged at $3000 \mathrm{rpm}$ for 30 minutes. The volume of the supernatant was noted in a $10 \mathrm{~mL}$ graduated cylinder. Water absorption (mg. $\mathrm{mL}^{-1}$ ) was calculated as the difference between the initial volume of water added to the sample and the volume of the supernatant. The same procedure was carried out to determine the oil absorption capacity. Additional studies were conducted to investigate the influence of ionic strength on water absorption capacity by varying the ionic strength of the medium using 0.1 , $0.2,0.4,0.6,0.8$ and $1.0 \mathrm{M} \mathrm{NaCl}$ solutions, respectively. Studies were conducted by triplicate.

\section{Emulsifying properties}

The emulsifying activity and stability were determined using the Neto et al. method (2001) with some modifications. Five milliliters of flour dispersion in distilled water $\left(10 \mathrm{mg} \cdot \mathrm{mL}^{-1}\right)$ was homogenized with $5 \mathrm{~mL}$ oil for 1 minute. The emulsions were centrifuged at $1100 \mathrm{rpm}$ for 5 minutes. The height $(\mathrm{cm})$ of emulsified layer (ELH) and height of the total content of the tube (TC) were measured. Emulsifying Capacity (EC) was calculated as EC $(\%)=(\mathrm{ELH} / \mathrm{TC}){ }^{\star} 100$. Emulsion stability (ES) was determined by heating the emulsion at $80{ }^{\circ} \mathrm{C}$ for 30 minutes before centrifuging at $1100 \mathrm{rpm}$ for 5 minutes and was calculated as ES $(\%)=($ ELHA/TCA $){ }^{*} 100$; where ELHA $=$ height of emulsified layer after heating $(\mathrm{cm})$ and TCA $=$ height of total content before heating $(\mathrm{cm})$. The effect of concentration on emulsifying activity and stability of flours was studied by preparing $2-10 \% \mathrm{w} / \mathrm{v}$ solution before conducting the experiments as described above. Influence of ionic strength was studied by preparing flour dispersions in water at $10 \mathrm{mg} \cdot \mathrm{mL}^{-1}$ of water in solution of various ionic strength: $0.1,0.2,0.4,0.6$, 0.8 and $1.0 \mathrm{M} \mathrm{NaCl}$.

\section{Foaming properties}

The method developed by Coffman and Garcia (1977) for the determination of foaming capacity and stability of the flours was used. Ten grams of flour were dispersed in $100 \mathrm{~mL}$ of distilled water, and this suspension was mixed vigorously for 2 minutes using a blender set at speed 2 . The initial solution volume $\left(\mathrm{V}_{1}\right)$ and final volume after mixing $\left(\mathrm{V}_{2}\right)$ were registered. Foaming Capacity $(\mathrm{FC})$ was calculated as $\mathrm{FC}=\left(\left(\mathrm{V}_{2}-\mathrm{V}_{1}\right) / \mathrm{V}_{1}\right){ }^{\star} 100$. Foaming Stability (FS) was determined as the foam volume that remained after 8 hours and was expressed as a percentage of the initial foam volume. The effect of flour concentration on the foaming properties of the dispersion was studied at concentrations of $2,4,6,8$ and $10 \% \mathrm{w} / \mathrm{v}$, respectively. The influence of ionic strength on the $\mathrm{FC}$ and FS was studied by dispersing $2 \mathrm{~g}$ of flour in $100 \mathrm{~mL}$ of $\mathrm{NaCl}$ solutions $(0.1$ to $1.0 \mathrm{M})$.

\section{Gelation properties}

Gelation properties were determined using the method described by Coffman and Garcia (1977). Sample suspensions of $2-10 \% \mathrm{w} / \mathrm{v}$ were prepared in distilled water. Ten milliliters of each prepared dispersion were transferred into a test tube. Each test tube was heated in a boiling water bath for 1 hour, cooled rapidly under running tap water, and further cooled for 2 hours in a refrigerator at $4{ }^{\circ} \mathrm{C}$. The least gelation concentration was taken as the concentration at which the sample did not fall from the inverted test tube. The effect of ionic strength was investigated by preparing sample suspensions $(2-20 \% \mathrm{w} / \mathrm{v})$ at various concentrations in $\mathrm{NaCl}$ solutions of varying ionic 
strength ranging from 0.1 to $1.0 \mathrm{M}$. The control analysis was performed by using the same concentrations of the flours but using distilled water instead of sodium chloride solutions. The minimum gelation concentration was determined as described above.

\subsection{Statistical analysis}

Triplicate data collections were used for the analysis. The statistical analysis of the results was performed with Statgraphics Plus $^{\oplus} 5.1$ and the Fisher test was used to determine significance of differences between means. A level of $\mathrm{p}<0.05$ was used to indicate significant differences.

\section{Results and discussion}

\subsection{Physicochemical properties of the seeds}

In order to compare the morphological characteristics of vitabosa and soybean, their physicochemical properties were evaluated, and the results are presented in Table 1. Analysis of variance indicated a significant difference between the weights of both seeds, being vitabosa the largest one. $M$. deeringiana weight was $0.91 \mathrm{~g}$, which is similar to other Mucuna species seeds (ADEBOWALE et al., 2005). Vitabosa had the lowest density compared with soybean and other Mucuna species (ADEBOWALE et al., 2005), but it was higher than other leguminous species (KAUR et al., 2007; KAUR; SINGH, 2005). M. deeringiana hydration and swelling capacities were higher than that of soybeans and other leguminous crops (SEENA; SRIDHAR, 2005; CHAVAN et al., 1999). These results might indicate that vitabosa is more permeable than soybeans. Vitabosa seeds showed higher moisture content and lower hydration rate than soybeans. However, the moisture result was very high when compared with that of other leguminous crops (VIDIVEL; JANARHANEN, 2001; CHAVAN et al., 1999; ALETOR; ALADETIMI, 1989). This might be a reflection of the relative hardness and impermeability of the seed coat. $M$. deeringiana may require shorter time for germination, soaking, or cooking which may be a favorable factor for the process or unfavorable for the possible reduction of its life time. The moisture content of soybean was higher than that found by Redondo-Cuenca et al. (2006).

\subsection{Functional properties of flours}

\section{Oil and Water absorption capacity}

The oil Absorption Capacity (OAC) of flours is presented in Table 2. A maximum lipophilic tendency of $1.82 \mathrm{~mL} \cdot \mathrm{g}^{-1}$ was observed for Vitabosa. This value was higher than that of M. pruriens flour (ADEBOWALE; LAWAL, 2004). In addition, the OAC value of Soybean was comparable to those reported for other leguminous flours (KAUR; SINGH, 2005; CHAU; CHEUNG, 1998), but higher than that reported by Mizubuti et al. (2000) for soybean flour.
This result suggests that vitabosa has more hydrophobic interaction sites than soybean. Variations in the presence of nonpolar side chains, which might bind the hydrocarbon side chains of oil among the flours, could explain differences in the oil binding capacity of the flours (ADEBOWALE; LAWAL, 2004). However, the flours are potentially useful for their structural interactions in food, especially for flavor retention, and to improve palatability and extension of shelf life in bakery or meat products, in which fat absorption is desirable (FENNEMA, 2000).

Water Absorption Capacity (WAC) was higher for soybean $\left(1.82 \mathrm{~mL} \cdot \mathrm{g}^{-1}\right)$ than for vitabosa flour $\left(1.27 \mathrm{~mL} \cdot \mathrm{g}^{-1}\right)$ (Figure 1). Intrinsic factors affecting WAC of food protein include size and shape of protein, steric factors, hydrophilic-hydrophobic balance of amino acids in the molecules, and lipids and carbohydrates present in the flour. The ionic strength affected significantly $(\mathrm{p}<0.05)$ the WAC of the flours. WAC was higher with an increased ionic strength of the solution up to $0.2 \mathrm{M}$. Further increases in ionic strength from 0.4 to 1.0 reduce the water absorption capacity of the flours progressively. Possibly, at higher salt concentrations of $0.2 \mathrm{M}$, the water binding capacity of proteins increases due to the fact that the hydrated salt ions are fixed (weakly) to the charged groups. At these concentrations, the fixation of ions to proteins does not affect the hydration shell of the charged groups, and the increase in water binding capacity is mainly due to the link between associated ions. However, at high salt concentrations a lot of the water present in the medium binds to salt ions, which determines the dehydration of the proteins (FENNEMA, 2000).

\section{Emulsifying properties}

The Emulsifying Activity (EA) and stability (ES) of the flours were concentration dependent as shown in Figures 2 and 3. Generally, the EA decreased as the concentration of flour in solution increased. This is similar to what was reported by Adebowale and Lawal (2004) in groundnut, beans, and velvet beans. The flours had higher EA at a concentration of $4 \%$. The

Table 1. Physicochemical properties of the Mucuna deeringiana and Soybean ${ }^{\mathrm{a}, \mathrm{b}}$.

\begin{tabular}{lcc}
\hline \multicolumn{1}{c}{ Parameter } & M. deeringiana & \multicolumn{1}{c}{ Soybean } \\
\hline Grain weight $(\mathrm{g})$ & $0.91 \pm 0.16^{\mathrm{a}}$ & $0.17 \pm 0.02^{\mathrm{b}}$ \\
Density $\left(\mathrm{g} \cdot \mathrm{mL}^{-1}\right)$ & $0.61 \pm 0.02^{\mathrm{a}}$ & $0.97 \pm 0.06^{\mathrm{b}}$ \\
Hydration capacity $\left(\mathrm{g} . \mathrm{seed}^{-1}\right)$ & $0.71 \pm 0.06^{\mathrm{a}}$ & $0.20 \pm 0.01^{\mathrm{b}}$ \\
Hydration index & $0.74 \pm 0.06^{\mathrm{a}}$ & $1.19 \pm 0.04^{\mathrm{b}}$ \\
Swelling capacity (mL.seed $\left.{ }^{-1}\right)$ & $0.75 \pm 0.02^{\mathrm{a}}$ & $0.22 \pm 0.01^{\mathrm{b}}$ \\
Swelling index & $0.50 \pm 0.01^{\mathrm{a}}$ & $1.09 \pm 0.06^{\mathrm{b}}$ \\
Moisture (\%) & $12.87 \pm 0.19^{\mathrm{a}}$ & $12.42 \pm 0.04^{\mathrm{b}}$ \\
\hline${ }^{\mathrm{a}}$ Results are expressed as means of triplicate determinations \pm SD. ${ }^{\mathrm{b}}$ Means followed by \\
different superscript within a row indicates significant differences at $\mathrm{p}<0.05$.
\end{tabular}

Table 2. Oil absorption capacity of flours ${ }^{\mathrm{a}, \mathrm{b}}$.

\begin{tabular}{cc}
\hline Flour & Oil absorption capacity $\left(\mathrm{mL}^{\mathrm{g}} \mathrm{g}^{-1}\right)$ \\
\hline Vitabosa $(\mathrm{V})$ & $1.82 \pm 0.01^{\mathrm{a}}$ \\
Soybean $(\mathrm{S})$ & $1.43 \pm 0.02^{\mathrm{b}}$ \\
\hline
\end{tabular}

${ }^{a}$ Results are expressed as means of triplicate determinations \pm SD. ${ }^{b}$ Means followed by different superscript within a row indicates significant differences at $\mathrm{p}<0.05$. 
emulsifying capacity of vitabosa flour (48.7\%) was similar to sorghum (49\%) (ELKHALIFA et al., 2005), but lower than that reported for Brassica carinata (75.6\%) (PEDROCHE et al., 2004), Sesamum indicum (83.0\%) and Vigna subterranean (78.5\%) (YUSUF et al., 2008). The emulsifying properties of leguminous products are the result of soluble and insoluble protein fractions and other components such as polysaccharides (McWATTERS; CHERRY, 1977). The unfolding of proteins at the interface water/oil plays an important role in the emulsifying capacity and stability due to increased hydrophobicity (JAYAPRAKASHA; BRUECKNER, 1999).

The emulsifying stability of flours increased progressively as the concentration increased until it began to decline with increasing flour concentrations from $6 \% \mathrm{w} / \mathrm{v}$ upward. Vitabosa exhibited the highest ES. These results are similar to what has been reported for other leguminous species (JITNGARMKUSOL et al., 2008, KAUR; SINGH, 2005). The ES of proteins is related to their ability to reduce the interfacial tension between oil and water in the emulsion. Surface activity is a function of the protein ability to migrate, absorb, deploy, and rearrange at an interface (OSHODI; OJOKAN, 1997).

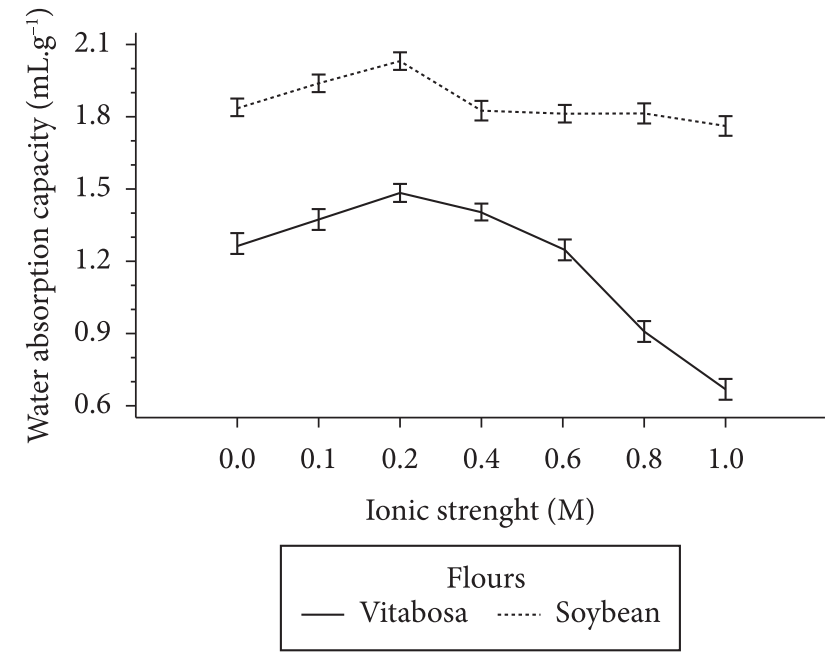

Figure 1. Effect of ionic strength on water absorption capacity of flours.

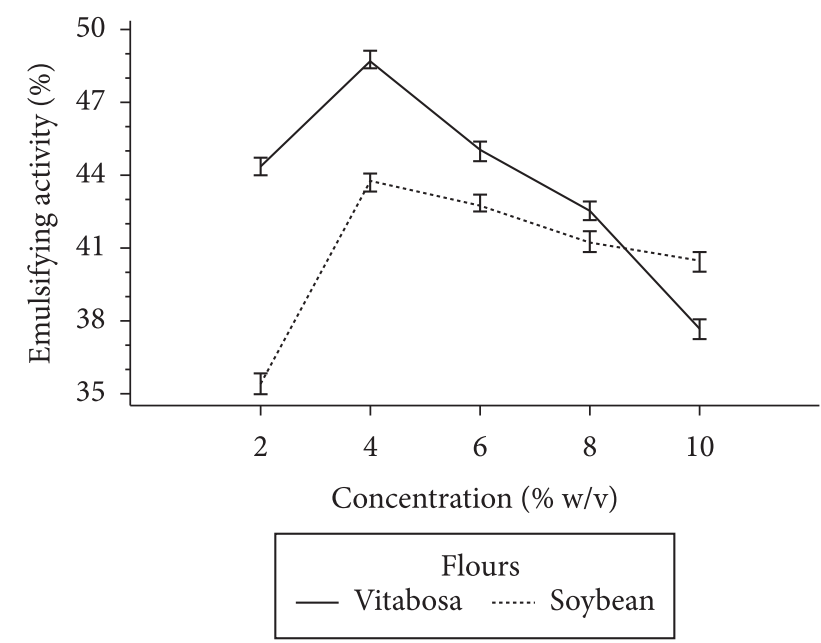

Figure 2. Effect of concentration on emulsifying activity of flours.
The presence of salt is a factor that plays an important role in the activity and stability of emulsions (see Figures 4,5 ). The emulsifying activity increased progressively to higher values in $0.4 \mathrm{M} \mathrm{NaCl}$ solutions (44.4\% for soybeans and $44.3 \%$ for vitabosa) and was followed by a decline. Significant differences

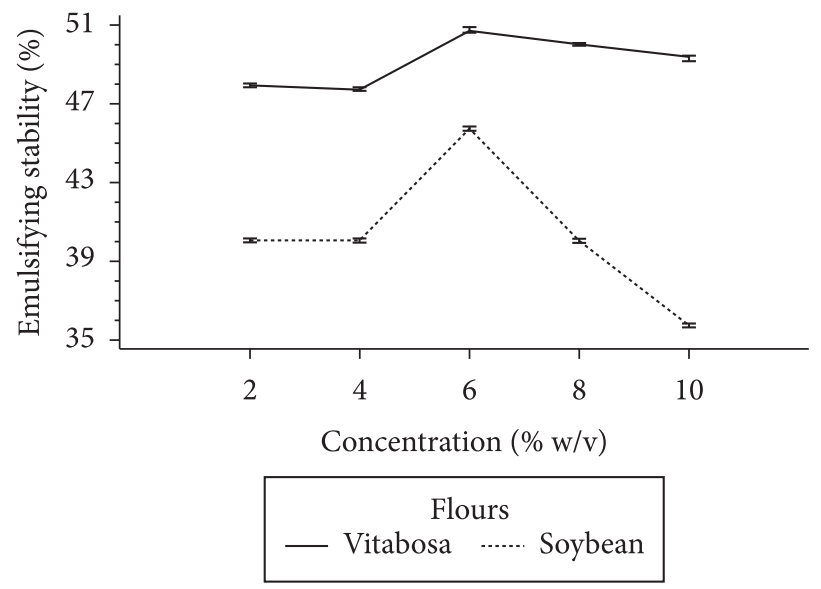

Figure 3. Effect of different concentrations on emulsifying stability.

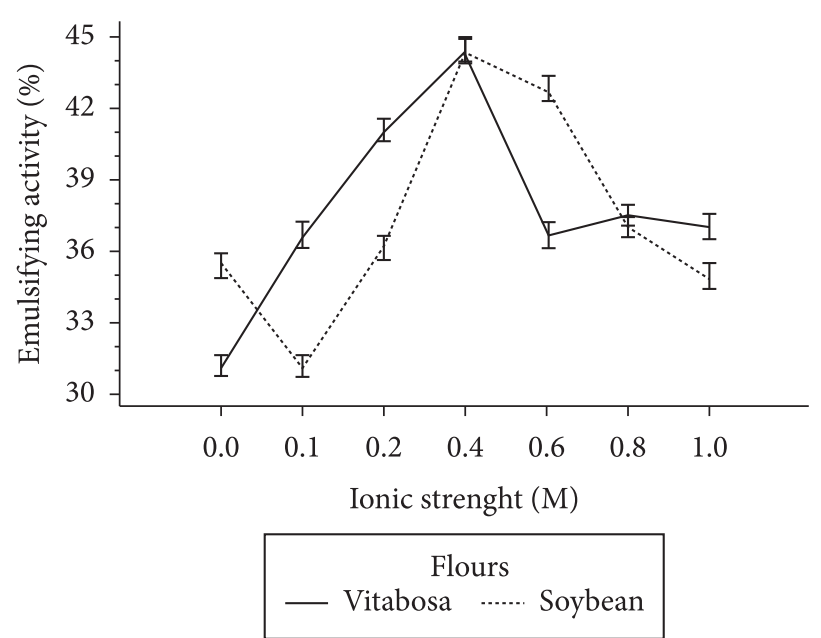

Figure 4. Effect of ionic strength on emulsifying activity of flours.

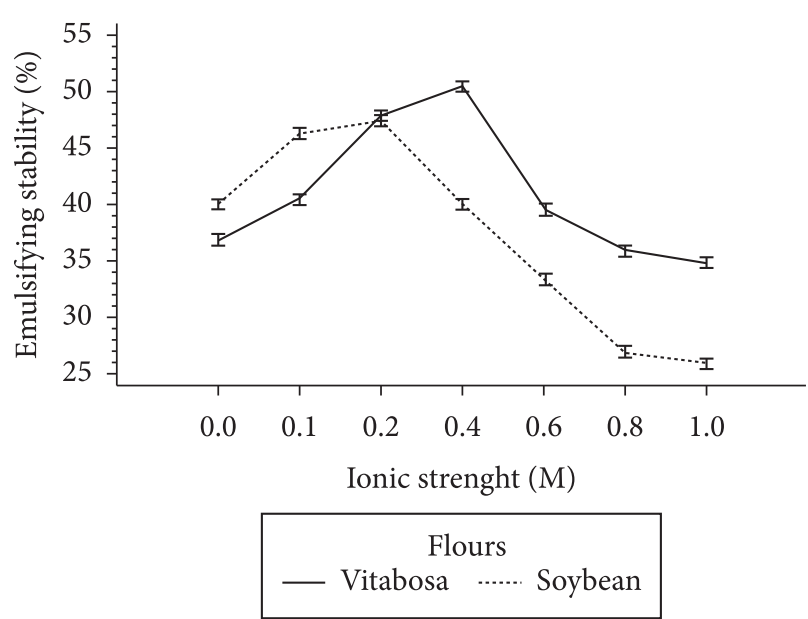

Figure 5. Effect of ionic strength on emulsion stability of flours. 
between solutions with different ionic strengths were observed, whereas no differences were found between the flours tested at concentrations of 0.4 and $0.8 \mathrm{M}$, respectively. Similarly, it was noted an increase in the emulsifying stability of flour for the values of $0.2 \mathrm{M}$ ionic strength for soybeans and $0.4 \mathrm{M}$ for vitabosa, respectively. At higher values, the ES decreases in flours. The soybean standard showed the highest emulsifying stability, but in saline solutions, the best ES corresponds to vitabosa at a concentration of $0.4 \mathrm{M}$. Wagner and Gueguen (1999) attribute the high ES of soybean protein solutions with low ionic strength to the oligomeric structure dissociation of glycinin $11 \mathrm{~S}$ and a consequent improvement in the surface behavior. The emulsifying properties of proteins depend basically on two effects: 1) a substantial decrease in interfacial energy due to absorption of the protein at the oil/water interface and 2) the electrostatic, structural, and mechanical energy barrier caused by the interfacial layer that opposes destabilization processes (WAGNER; GUEGEN, 1999).

Salt can affect emulsifying properties by two mechanisms: 1) $\mathrm{NaCl}$ can reduce the electrostatic repulsion between emulsion droplets and the concentration of electrolytes, and 2) high concentrations of ions can alter the structural organization of water molecules, which disturbs the strength of hydrophobic interactions among non-polar groups (McCLEMENTS, 1999). The initial increase in the ionic strength of the solutions up to $0.4 \mathrm{M}$ enhanced the formation of charged layers around the fat globules, which resulted in mutual repulsion among them. Low ionic strength levels form a hydrated layer around the interfacial material, which causes a decrease in the interfacial energy and retards the coalescence. A high ionic strength $(0.6-1.0 \mathrm{M})$ decreases the unfolding capacity of the protein, which probably limits its absorption at the oil/water interface. Although vitabosa had the best ES, the statistical analysis found no significant differences between the flours indicating that two samples are potentially useful in food formulations, such as milk drinks, meat, and similar products.

\section{Foaming properties}

The effect of concentration on Foam Capacity (FC) is presented in Table 3. FC of vitabosa increased from $41 \%$ in a $4 \% \mathrm{w} / \mathrm{v}$ solution to $58 \%$ in $6 \% \mathrm{w} / \mathrm{v}$ solution respectively, after which its foam capacity was reduced progressively when the concentration of flour in solution increased and a minimum value of $49 \%$ was recorded in $8 \% \mathrm{w} / \mathrm{v}$ solution. Soybean presented a progressive increase up to $37 \%$ in $8 \% \mathrm{w} / \mathrm{v}$ solution. The analysis of variance showed significant differences between the flours and their concentration. The best FC was that of the vitabosa (57.8\%), which was lower than the FC of other leguminous species such as Sesamum indicum (82\%) and Vigna subterranean (70\%) (YUSUF et al., 2008) but higher than the FC of peanuts (10-13\%) (KAUR; SINGH, 2005), peanut protein concentrate (20-40\%) (WU et al., 2009), Pisum sativum (39-42\%), and Cajanus cajan (34-37\%) (KAUR et al., 2007).

Akintayo et al.(1999) associated good foam capacity with the flexibility of protein molecules reducing the surface tension and highly ordered globular protein, which hinders surface denaturation and leads to a low Foaming Capacity (FC). The reason why the flours are capable of producing foam is that proteins have an active surface. Soluble proteins can reduce the surface tension at the interface between air bubbles and the fluid that surrounds them; therefore, coalescence is blocked. Moreover, protein molecules can be deployed and interact with each other to form a multilayer or film protein with increased flexibility of the air-liquid interface. As a result, it is harder to break bubbles and foam is more stable (ADEBOWALE LAWAL, 2003).

Foam Stability (FS) of the flours increased with the concentration in the solution (Table 4). The best FS was found for vitabosa flour for $10 \% \mathrm{w} / \mathrm{v}$ solution. The analysis of variance indicated a significant effect on flours. High FS was found for vitabosa in all concentrations tested. In soybeans, from $2 \%$ to $4 \% \mathrm{w} / \mathrm{v}$ solutions, the foam did not remain stable for 8 hours, but at higher concentrations the results were acceptable. A higher protein concentration creates protein-protein interactions at the air-water interface, and it also promotes the formation of a multilayer film that offers a high viscoelastic resistance to bubbles coalescence, which increases the foam stability.

The effect of ionic strength on foam capacity is presented in Table 5. There was a significant rise ( $>95 \%)$ in the FC of vitabosa flour by increasing the ionic strength from 0.0 to $0.6 \mathrm{M}$. At higher $\mathrm{NaCl}$ concentration values, the FC decreased. Soybean flour presented a similar behavior. The effect of ionic strength on foam stability is shown in Table 6. The Analysis of Variance indicated significant differences between the flours and $\mathrm{NaCl}$ concentrations. The increase in ionic strength from 0.0 to $0.2 \mathrm{M}$ led to increased FS of vitabosa flour from 29 to $46 \%$ respectively. The maximum value (56\%) was obtained for $0.4 \mathrm{M}$. Initially, soybean had a reduction in the FS from 22 to $20 \%$ from 0.0 to $0.2 \mathrm{M}$, but at $0.4 \mathrm{M}$ it began to increase reaching a maximum value of $40 \%$ for a $0.8 \mathrm{M}$ salt solution. These results are similar to those of previous studies, in which foam stability increases with the addition of salts (WU et al., 2009; LINARES et al., 2000). Furthermore, Akintayo et al. (1999) found a measure of the influence of ionic strength on the foam properties on Cajanus cajan concentrates. In this report, the increase in ionic strength from 0.0 to $0.5 \mathrm{M}$ increased the FA from 80 to $100 \%$, while values close to $1.0 \mathrm{M}$ reduced the FC by $50 \%$. The changes

Table 3. Effect of concentration on foam capacity of flours ${ }^{\mathrm{a}, \mathrm{b}}$.

\begin{tabular}{lccccc}
\hline Sample & \multicolumn{5}{c}{ Concentration (\% w/v) } \\
\cline { 2 - 5 } & 2 & 4 & 6 & 8 & 10 \\
\hline Vitabosa & $31.44 \pm 1.2^{\mathrm{a}}$ & $41.2 \pm 1.8^{\mathrm{b}}$ & $57.85 \pm 1.5^{\mathrm{c}}$ & $48.84 \pm 2.0^{\mathrm{c}}$ & $51.51 \pm 2.5^{\mathrm{d}}$ \\
Soybean & $21.33 \pm 2.6^{\mathrm{d}}$ & $26.09 \pm 1.7^{\mathrm{c}}$ & $29.47 \pm 1.2^{\mathrm{b}}$ & $37.21 \pm 0.2^{\mathrm{b}}$ & $29.01 \pm 1.8^{\mathrm{a}}$ \\
\hline${ }^{\text {a}}$ Results are expressed as means of triplicate determinations \pm SD. ${ }^{\mathrm{b}}$ Means followed by \\
different superscript within a row indicates significant differences at $\mathrm{p}<0.05$.
\end{tabular}

Table 4. Effect of concentration on foam stability of flours ${ }^{\mathrm{a}, \mathrm{b}}$.

\begin{tabular}{cccccc}
\hline Sample & \multicolumn{5}{c}{ Concentration (\% w/v) } \\
\cline { 2 - 6 } & 2 & 4 & 6 & 8 & 10 \\
\hline Vitabosa & $33.32 \pm 0.8^{\mathrm{a}}$ & $35.51 \pm 1.7^{\mathrm{a}}$ & $36.95 \pm 3.2^{\mathrm{b}}$ & $33.06 \pm 2.3^{\mathrm{c}}$ & $39.07 \pm 0.82^{\mathrm{d}}$ \\
Soybean & 0 & 0 & $17.82 \pm 2.0^{\mathrm{a}}$ & $28.50 \pm 2.1^{\mathrm{a}}$ & $33.65 \pm 1.3^{\mathrm{a}}$ \\
\hline
\end{tabular}

${ }^{a}$ Results are expressed as means of triplicate determinations \pm SD. ${ }^{b}$ Means followed by different superscript within a row indicates significant differences at $\mathrm{p}<0.05$. 
Table 5. Effect of ionic strength on foam capacity of flours ${ }^{\mathrm{a}, \mathrm{b}}$.

\begin{tabular}{|c|c|c|c|c|c|c|c|}
\hline \multirow[t]{2}{*}{ Sample } & \multicolumn{5}{|c|}{ Ionic strength $(\mathrm{M})$} & \multirow[b]{2}{*}{0,8} & \multirow[b]{2}{*}{1,0} \\
\hline & 0 & 0,1 & 0,2 & 0,4 & 0,6 & & \\
\hline Vitabosa & $28.67 \pm 2.6^{a}$ & $40.87 \pm 0.9^{b}$ & $45.82 \pm 0.6^{c}$ & $49.83 \pm 0.9^{d}$ & $56.53 \pm 1.5^{\mathrm{d}}$ & $40.06 \pm 0.4^{\mathrm{e}}$ & $28.90 \pm 0.8^{f}$ \\
\hline Soybean & $20.67 \pm 0.9^{f}$ & $25.39 \pm 1.4^{\mathrm{e}}$ & $36.00 \pm 0.8^{\mathrm{d}}$ & $47.16 \pm 1.8^{c}$ & $39.41 \pm 1.1^{\mathrm{c}}$ & $34.88 \pm 0.1^{\mathrm{b}}$ & $33.33 \pm 0.9^{\mathrm{a}}$ \\
\hline
\end{tabular}

Table 6. Effect of ionic strength on foam stability of flours ${ }^{\text {a.b }}$.

\begin{tabular}{|c|c|c|c|c|c|c|c|}
\hline \multirow[t]{2}{*}{ Sample } & \multicolumn{5}{|c|}{ Ionic strength $(\mathrm{M})$} & \multirow[b]{2}{*}{0.8} & \multirow[b]{2}{*}{1} \\
\hline & 0 & 0.1 & 0.2 & 0.4 & 0.6 & & \\
\hline Vitabosa & $29.39 \pm 1.2^{\mathrm{a}}$ & $41.87 \pm 0.6^{\mathrm{bc}}$ & $48.87 \pm 1.6^{c}$ & $56.63 \pm 2.1^{d}$ & $45.83 \pm 0.4^{\mathrm{e}}$ & $43.73 \pm 3.5^{f}$ & $30.44 \pm 1.0^{\mathrm{b}}$ \\
\hline Soybean & $22.61 \pm 2.5^{\mathrm{f}}$ & $21.0 \pm 1.4^{\mathrm{ae}}$ & $20.14 \pm 6.05^{\mathrm{e}}$ & $24.23 \pm 1.1^{c}$ & $37.13 \pm 1.7^{\mathrm{d}}$ & $40.36 \pm 1.1^{\mathrm{b}}$ & $30.11 \pm 1.6^{\mathrm{a}}$ \\
\hline
\end{tabular}

${ }^{a}$ Results are expressed as means of triplicate determinations \pm SD. ${ }^{b}$ Means followed by different superscript within a row indicates significant differences at $\mathrm{p}<0.05$.

observed in flours with different ionic strength solutions can be caused by physiological differences in the composition of protein and the presence of other compounds such as lipids and carbohydrates in different proportions. The increased FS in vitabosa and soybean can be attributed to an increase in protein solubility due to partial denaturation (SOSULSKI; McCURDY, 1987). Salt concentration increases the ability of adhesion between protein molecules, and there is a greater possibility of formation of interfacial proteins with stronger rheological properties that maintain the integrity of the foam when the FS in soybean increased to 0.8 . For vitabosa, higher $\mathrm{NaCl}$ concentrations reduce the denaturation of proteins at the surface to provide the rheological with properties necessary for a higher stability of the foam. Giami (1993) found similar results for Vigna unguiculata flour.

\section{Gelation capacity}

The effect of ionic strength and concentration on the Gelation Capacity (GC) of flours is presented in Table 7. The best GC was obtained for vitabosa. Adebowale and Lawal (2004) reported gelation capacity of 14,16 , and $18 \% \mathrm{w} / \mathrm{v}$ for Canavalia ensiformis, Voandzeia subterranean and Mucuna pruriens, respectively. The minimum GC for Pisum sativum and Cajanus cajan was $12 \%$ (KAUR et al., 2007). This indicates that the results obtained for vitabosa are better than those found by these authors. The gelation properties variation can be attributed to the sizes of the various constituents such as proteins, carbohydrates, and lipids suggesting that the interaction between these components may also play an important role in the functional properties (KAUR et al., 2007). Protein gelation is very important in the development and acceptability of many foods, including vegetables and other products. The gelation mechanism and gel appearance are mainly controlled by the balance between attractive hydrophobic interactions and repulsive electrostatic interactions (EGELANDSAL, 1980; KOJIMA; NAKAMURA, 1985).

Increasing ionic strength decreased the $\mathrm{GC}$ of the flours compared with that of the control. Vitabosa was less affected by the ionic strength than soybean, which showed a lower gelation degree. The GC of vitabosa remained stable (14\%) with increasing ionic strength until it reached $0.4 \mathrm{M}$; condition after which the necessary amount of flour to form gel increased. Although no changes were observed in the GC
Table 7. Effect of concentration and ionic strength on gelation capacity of flours ${ }^{\star a, b}$.

\begin{tabular}{lccccccc}
\hline Sample & Control & \multicolumn{6}{c}{ Ionic strength $(\mathrm{M})$} \\
\cline { 3 - 7 } & & 0.1 & 0.2 & 0.4 & 0.6 & 0.8 & 1.0 \\
\hline Vitabosa & $10^{\mathrm{a}}$ & $10^{\mathrm{a}}$ & $10^{\mathrm{a}, \mathrm{b}}$ & $10^{\mathrm{b}}$ & $12^{\mathrm{c}}$ & $14^{\mathrm{c}}$ & $16^{\mathrm{d}}$ \\
Soybean & $14^{\mathrm{d}}$ & $14^{\mathrm{d}}$ & $14^{\mathrm{c}, \mathrm{d}}$ & $16^{\mathrm{c}}$ & $20^{\mathrm{b}}$ & $20^{\mathrm{b}}$ & $20^{\mathrm{a}}$ \\
\hline *Values are least gelation concentration expressed as \% w/v. Results are expressed as \\
means of triplicate determinations $\pm \mathrm{SD}$. ${ }^{\mathrm{b}}$ Means followed by different superscript within \\
a row indicates significant differences at $\mathrm{p}<0.05$.
\end{tabular}

$(14 \% \mathrm{w} / \mathrm{v})$ of soybean from 0.1 to $0.2 \mathrm{M}$, an increase in ionic strength up to $0.4 \mathrm{M}$ raised the GC again, and it reached the highest value of $20 \% \mathrm{w} / \mathrm{v}$ at $0.60 \mathrm{M}$. Akintayo et al. (1999) attributed the improvement in GC at low ionic strength to enhanced protein solubilization in the salt solution, which created an effective overlapping of the functional groups between adjacent protein molecules, a necessary condition for gel network formation. Adebowale and Adebowale (2008) found an improvement of the gelation characteristics with increasing ionic strength to $0.4 \mathrm{M}$, but higher values would adversely affect the GC of flour and Mucuna protein concentrates. Otte et al. (1999) reported that during gelation of whey protein isolated, the gel firmness decreased with increasing salt content.

\section{Conclusions}

Vitabosa flour (Mucuna deeringiana) presents different physicochemical and functional properties of soybean flour (Glycine max). Soybean has a higher density, moisture, hydration, and swelling capacity than $M$. deeringiana. The emulsifying activity of vitabosa and soybean decreased as the concentration of flour increased. The best emulsifying activity was found for vitabosa at $4 \%(\mathrm{w} / \mathrm{v})$ concentration. The Emulsifying Stability increased progressively as the concentration increased up to $6 \%$. The best ES was found for vitabosa at $6 \%$. The increase in ionic strength up to $0.4 \mathrm{M}$ improved the emulsifying capacity and stability of the flours; however, at higher values, these characteristics were significantly reduced. The effect of concentration on foam capacity varied for each sample, and foam stability increased with increasing concentration. Increasing ionic strength decreased the gelation 
capacity of the flours. The variation in soybean and vitabosa functional properties could be related to the size, quality, and quantity of protein, starch, and other essential constituents.

\section{References}

ADEBOWALE, Y.; ADEBOWALE, K. Evaluation of the gelation characteristics of the Mucuna bean flour and protein isolate. Electronic Journal of Environmental, Agricultural and Food Chemistry, v. 7, p. 3206-3222, 2008.

ADEBOWALE, Y. et al. Variability in the physicochemical, nutritional and antinutritional attributes of six Mucuna species. Food Chemistry, v. 89, p. 37-48, 2005. http://dx.doi.org/10.1016/j. foodchem.2004.01.084

ADEBOWALE, K.; Y LAWAL, O. Comparative study of the functional properties of bambarra groundnut (Voandzeia subterranean) jack bean (Canavalia ensiformis) and Mucuna bean (Mucuna pruriens) flours. Food Research International, v. 37, p. 355-365, 2004. http:// dx.doi.org/10.1016/j.foodres.2004.01.009

ADEBOWALE, K.; LAWAL, O. Foaming, gelation and electrophoretic characteristics of mucuna bean (Mucuna pruriens) protein concentrates. Food Chemistry, v. 83, p. 237-246, 2003. http://dx.doi. org/10.1016/S0308-8146(03)00086-4

AKINTAYO, E. et al. Effects of $\mathrm{NaCl}$, ionic strength and $\mathrm{pH}$ on the foaming and gelation of pigeon pea (Cajanus cajan) protein concentrates. Food Chemistry, v. 66, p. 51-56, 1999. http://dx.doi. org/10.1016/S0308-8146(98)00155-1

ALETOR, V. A.; ALADETIMI, O. Compositional evaluation of some cowpea varieties and some underutilised legumes in Nigeria.Die Nahrung, v. 37, p. 999-1007, 1989. http://dx.doi.org/10.1002/ food.19890331023

ARANGO, L. Efecto de la variabilidad espacial de algunas propiedades físicas y químicas del suelo relacionadas con la producción del forraje del pasto ángleton (Dichanthium aristatum (Poir) C. E. Hubbard). 2004. 78 f. Tesis (Maestría en Geomorfología y Suelos)-Facultad de Ciencias, Universidad Nacional de Colombia, Medellín, 2004.

ASSOCIATION OF OFFICIAL ANALYTICAL CHEMISTS - AOAC. Official Methods of Analysis. 16. ed. Washington: AOAC, 2000.

BEUCHAT, L. R. Functional and electrophoretic characteristics of succinylated peanut flour protein. Journal of Agricultural and Food Chemistry, v. 25, p. 258-261, 1977. http://dx.doi.org/10.1021/ jf60210a044

CHAVAN, U. D. et al. Physicochemical properties and nutrient composition of beach pea (Lathyrus maritimus L.). Food Chemistry, v. 66, p. 43-50, 1999. http://dx.doi.org/10.1016/S03088146(98)00096-X

CHAU, C. F.; CHEUNG, P. C. Functional properties of flours prepared from three Chinese indigenous legume seeds. Food Chemistry, v. 61, p. 429-433, 1998. http://dx.doi.org/10.1016/ S0308-8146(97)00091-5

COFFMAN, C. W.; GARCIA, V. V. Functional properties and amino acid content of protein isolate from mung bean flour. Journal of Food Technology, v. 12, p. 473-484, 1977. PMid:21848869. http:// dx.doi.org/10.1111/j.1365-2621.1977.tb00132.x

ECHEVERRI, C.; RODRÍGUEZ, H. La Vitabosa (Mucuna Deeringiana). Antioquia: Servicio Nacional de Aprendizaje SENA; Rionegro: Centro Multisectorial de Oriente, 1999.
EGELANDSAL, B. Heat induced gelling in solutions of ovalbumin. Journal of Food Science, v. 45, p. 570-573, 1980. http://dx.doi. org/10.1111/j.1365-2621.1980.tb04103.x

ELKHALIFA, A. E. et al. Effect of fermentation on the functional properties of sorghum flour. Food Chemistry, v. 92, p. 1-5, 2005. http://dx.doi.org/10.1016/j.foodchem.2004.05.058

FENNEMA, O. Química de los Alimentos. Editorial Acribia, 2000. p. 434-444.

GIAMI, S. Y. Effects of processing on the proximate composition and functional properties of cowpea (Vigna unguiculata) flour. Food Chemistry, v. 47, p. 153-158, 1993. http://dx.doi.org/10.1016/03088146(93)90237-A

JAYAPRAKASHA, H.; BRUECKNER, H. Whey protein concentrate: A potential functional ingredient for food industry. Journal of Food Science and Technology, v. 36, p. 189-204, 1999.

JITNGARMKUSOL, S. et al. Chemical compositions, functional properties, and microstructure of defatted macadamia flours. Food Chemistry, v. 110, p. 23-30, 2008. http://dx.doi.org/10.1016/j. foodchem.2008.01.050

KAUR, M. et al. Comparative study of the functional, thermal and pasting properties of flours from different field pea (Pisum sativum L.) and pigeon pea (Cajanus cajan L.) cultivars. Food Chemistry, v. 104, p. 259-267, 2007. http://dx.doi.org/10.1016/j. foodchem.2006.11.037

KAUR, M.; SINGH, N. Studies on functional, thermal and pasting properties of flours from different Chickpea (Cicer arietinum L.) cultivars. Food Chemistry, v. 91, p. 403-411, 2005. http://dx.doi. org/10.1016/j.foodchem.2004.06.015

KOJIMA, E.; NAKAMURA, R. Heat gelling properties of hen's egg yolk low density lipoprotein (LDL) in the presence of other proteins. Journal of Food Science, v. 50, p. 63-66, 1985. http://dx.doi. org/10.1111/j.1365-2621.1985.tb13278.x

LINARES, E. et al. Emulsifying and foaming properties of gluten hydrolysates with an increasing degree of hydrolysis: Role of soluble and insoluble fractions. Cereal Chemistry, v. 77, p. 414-420, 2000. http://dx.doi.org/10.1094/CCHEM.2000.77.4.414

MACHUKA, J. Characterisation of the seed proteins of velvet bean (Mucuna pruriens) from Nigeria. Food Chemistry, v. 68, p. 421-427, 2002. http://dx.doi.org/10.1016/S0308-8146(99)00211-3

McCLEMENTS, D. J. Emulsion stability. In: McCLEMENTS, D. J. Food emulsions: Principles, practice, and techniques. Boca Raton; London; New York; Washington: CRC Press, 1999. p. 185-233.

McWATTERS, K. H., Y; CHERRY, J. P. Emulsification, foaming and protein solubility properties of defatted soybean, peanut, fieldpea and pecan flours. Journal of Food Science, v. 42, p. 1444-1450, 1977. http://dx.doi.org/10.1111/j.1365-2621.1977.tb08395.x

MIZUBUTI, I. Y. et al. Functional properties of pigeon pea (Cajanus cajan (L.) Millsp.) flour and protein concentrate. Archivos Latinoamericanos De Nutrición, v. 50, n. 3, p. 274-280, 2000.

NETO, V. Q. et al. Functional properties of raw and heat-processed cashew nut (Anarcardium occidentale L.) kernel protein isolate. Nahrung, v. 45, p. 258-262, 2001. http://dx.doi.org/10.1002/15213803(20010801)45:4\%3C258::AID-FOOD258\%3E3.0.CO;2-3

OSHODI, A.; OJOKAN, E. Effect of salts on some of the functional properties of bovine plasma protein concentrate. Food Chemistry, v. 59, p. 333-338, 1997. http://dx.doi.org/10.1016/S03088146(96)00102-1

OTTE, J. et al. Protease induced gelation of unheated and heated whey proteins: Effects of $\mathrm{pH}$, temperature and concentration of 
proteins, enzyme and salts. International Dairy Journal, v. 9, p. 801-812, 1999. http://dx.doi.org/10.1016/S0958-6946(99)00151-X

PEDROCHE, J. et al. Brassica carinata protein isolates: chemical composition, protein characterization and improvement of functional properties by protein hydrolysis. Food Chemistry, v. 88, p. 337-346, 2004. http://dx.doi.org/10.1016/j.foodchem.2004.01.045

REN, H. et al. Antimutagenic and anti-oxidative activities found in Chinese traditional soybean fermented products furu. Food Chemistry, v. 95, p. 71-76, 2006. http://dx.doi.org/10.1016/j. foodchem.2004.12.019

REDONDO-CUENCA, A. et al. Chemical composition and dietary fibre of yellow and green commercial soybeans (Glycine max). Food Chemistry, v. 101, p. 1216-1222, 2006. http://dx.doi.org/10.1016/j. foodchem.2006.03.025

ROSTAGNO, M. et al. Short-term stability of soy isoflavones extracts: sample conservation aspects. Food Chemistry, v. 93, p. 557-564, 2005. http://dx.doi.org/10.1016/j.foodchem.2004.12.035

SIDDHURAJU, P. et al. Chemical composition, protein fraction, essential amino acid potential and antimetabolic constituents of an unconventional legume, Gila bean (Entada phaseoloides Merrill) seed kernel. Journal of the Science of Food and Agriculture, v. 82, p. 192-202, 2001. http://dx.doi.org/10.1002/jsfa.1025

SEENA, S.; SRIDHAR, K. Physicochemical, functional and cooking properties of under explored legumes, Canavalia of the southwest coast of India. Food Research International, v. 38, p. 803-814, 2005. http://dx.doi.org/10.1016/j.foodres.2005.02.007
SOSULSKI, F; McCURDY, A. Functionality of flours, protein fractions and isolates from field pea and faba beans. Journal of Food Science, v. 52, p. 1010, 1987. http://dx.doi.org/10.1111/j.1365-2621.1987. tb14263.x

VALDIVEL, V. Nutritional and anti-nutritional composition of velvet bean: an under-utilized food legume in South India. International Journal of Food Sciences and Nutrition, v. 51, p. 279-287, 2000. PMid:11027039. http://dx.doi.org/10.1080/09637480050077167

VIDIVEL, V:; JANARDHANEN, K. Nutritional and antinutrient attributes of the underutilized legume Cassia floribunda car. Food Chemistry, v. 73, p. 209-215, 2001. http://dx.doi.org/10.1016/ S0308-8146(00)00280-6

WAGNER, J.; GUEGUEN, J. Surface functional properties of native, acid treated and reduced soy glycinin. 2. Emulsifying properties. Journal of Agricultural and Food Chemistry, v.47, p. 2181-2187, 1999. PMid:10794606. http://dx.doi.org/10.1021/jf9809784

WU, H. et al. Comparative studies on the functional properties of various protein concentrate preparations of peanut protein. Food Research International, v. 42, p. 343-348, 2009. http://dx.doi. org/10.1016/j.foodres.2008.12.006

YUSUF, A. et al. Chemical composition and functional properties of raw and roasted Nigerian benniseed (Sesamum indicum) and bambara groundnut (Vigna subterranean). Food Chemistry, v. 111, p. 277-282, 2008. http://dx.doi.org/10.1016/j.foodchem.2007.12.014 